\title{
Samfundslederskab i en fragmenteret tidsalder
} Af Peter Aagaard *)

\section{Resumé}

Med udgangspunkt i teori om policy entreprenuerer og diskursiv institutionalisme indkredser artiklen et begreb om samfundsledelse. Samfundsledelse ses som en form for ledelse, der vokser frem i disse år i takt med liberale demokratiers krise. Samfundslederskab udspiller sig blandt mediebevidste politiske aktører, der ikke indgår i embedsværket eller er valgt til et formelt, politisk embede. Artiklen diskuterer dernæst kritisk borgernes relationer til disse samfundsledere, samt hvorvidt at det er muligt at initiere mere borgernære former for samfundslederskab. Artiklen anvender samfundslederskab i Danmark som illustrativ case og diskuterer afsluttende, i hvilket omfang danske forhold kan ses som en paradigmatisk case på samfundslederskab i Skandinavien.

\section{A: Indledning}

\section{Baggrund}

Vestlige, liberale demokratier er i krise. Populismen er på fremmarch, mens den ene krise afløser den anden - fra økologisk krise og finanskrise til social krise. Sammenhængskraft er nedadgående, uligheden stiger og borgerne giver udtryk for en generel mistillid til de politiske institutioner og den politiske elite (Foa \& Mounk, 2016; Fukuyama, 2014: 486). Så der er brug for ledelse.

*) Peter Aagaard er lektor på Roskilde Universitet. 
Men hvem kan og skal tage ansvaret på sig? Politikerne er historisk upopulære. Parlamenter i Skandinavien beskrives ganske vist som mere magtfulde end tidligere (Munk Christiansen \& Rommetvedt, 1999; Rommetvedt, Thesen, Christiansen, \& Norgaard, 2012), men de politiske partier beskrives også som kampagnemaskiner, der tenderer mod at være tømt for indhold og reel debat (Svallfors, 2016c). Så hvis ikke det er politikerne, der kan - eller er i stand til at tage lederskabet på sig, hvem skal så? Hvem leder i det hele taget liberale demokratier, kunne man også spørge? Er det regeringen? Politikerne? Særinteresser? Medierne?

Liberale demokratier er komplekse og sammensatte. Der er mange eliter: foruden den politiske elite rummer liberale demokratier typisk en kulturelite, en medieelite, en uddannelseselite, en erhvervselite mv. (Etzioni-Halevy, 1990). Det betyder, at liberale demokratier på mange måder er vanskelige at lede fra centralt hold. Der er derfor ganske meget ledelse af samfundet, der ikke i formel forstand er klassisk politisk ledelse (Garsten \& Sörbom, 2017). Den form for ledelse kan vi kalde samfundsledelse. Den har været her længe, men i mange lande er den blevet tydeligere i de senere år, i takt med kriserne har indfundet sig og har udstillet det formelle politiske system som begrænset i sine muligheder for at forandre og transformere samfundet (Olsen, 1978).

\section{Artiklens formål}

Skal vi derfor identificere lederskab i tidens liberale demokratier, så skal der en ganske anden optik til end den klassiske og formelle form for politisk ledelse. Med Danmark som illustrativ case er formålet med denne artikel at skitsere en ny optik på ledelse, der kan identificere samfundslederskab i den skandinaviske udgave af det liberale demokrati. Der er selvfølgelig forskelle på de skandinaviske lande, men også store ligheder i kraft af kulturel homogenitet, høje indkomst- og uddannelsesniveauer, samt stærke traditioner for samtale- og deltagelsesdemokrati. Forskningsspørgsmålet er: Hvad er samfundslederskab, og hvordan kommer det til udtryk i et land som Danmark? Hvem er udøverne af samfundsledelse i Danmark, hvordan bedriver de samfundsledelse, og med hvilke konsekvenser for demokratiet?

I næste afsnit vil jeg først forsøge at indkredse mit begreb om samfundslederskab i liberale demokratier, med udgangspunkt i teori om policy entreprenuership (Kingdon, 2015; Mintrom \& Norman, 2009) og diskursiv institutionalisme (Schmidt 2008). Danske forhold vil løbende blive brugt som illustrative eksempler. Samfundsledelse anskues i denne del af artiklen som et deskriptivt begreb, som kan udgøre en væsentlig og afgørende funktion i den institutionelle 
ordens tilpasning og transformation, men langt fra altid udfylder den funktion. I denne del af artiklen interesserer jeg mig altså ikke for, hvorvidt det givne formål med samfundsledelse er godt.

I artiklens anden del vil jeg dog kritisk diskutere de demokratiske konsekvenser af den form for samfundslederskab, vi har i Danmark, samt muligheden for at etablere et mere borgernært samfundslederskab. Afsluttende diskuterer jeg, hvorvidt danske forhold kan generaliseres til de andre skandinaviske lande, samt om samfundslederskab kan ses som løsning eller symptom på det liberale demokratis aktuelle udfordringer. Målet er dog hverken at kategorisere samfundsledere som systembevarende eller progressive, alene i kraft af deres position som ny samfundselite. Her er det naturligvis vigtigt at huske på, at der også var eliter i 'gamle dage'. Det korporative system, der tidligere dominerede den politiske proces i de skandinaviske lande, var ikke nødvendigvis mere demokratisk end det system af privilegeret pluralisme og policy professionalisme, der er opstået i de senere år. Udviklingen af samfundslederskab er derfor ikke en forfaldshistorie, men det er heller ikke nødvendigvis en fortælling om fremskridt.

\section{B. Den institutionelle orden i medialiseret demokrati}

I teoriafsnittets første del vil jeg beskrive den herskende institutionelle orden, hvor i samfundslederskab udspiller sig. Det vil ske ved hjælp af en række bidrag til institutionel teori (Cohen, March, \& Olsen, 1972; Kingdon, 2001), herunder ikke mindst Vivian Schmidts diskursive institutionalisme. Udgangspunktet er, at diskurser, medier og den politiske kommunikation af nye ideer fylder mere end tidligere i moderne politikskabelse (Binderkrantz, Christiansen, \& Pedersen, 2015; Aagaard, 2017; Aagaard \& Blach-Ørsten, 2018). I afsnittets anden del vil jeg så beskrive samfundsledernes rolle med udgangspunkt i teori om policy entrepreneuere (Mintrom \& Vergari, 1996). Løbende bruges danske forhold som illustrative eksempler.

\section{Policysfæren}

Ifølge Schmidt består samfundet af to sfærer: policy sfæren og den kommunikative sfære (2008:310). Policy sfæren kan ses som hjemsted for 'eliternes elite' (Etzioni-Halevy, 1990) Det vil sige toppen af de ministerielle departementer, toppolitikere, udvalgte eksperter og formænd $\mathrm{m} / \mathrm{k}$ for de privilegerede organiserede interesser (Binderkrantz et al 2015). Disse aktører har typisk 
stor indflydelse på (re)produktionen af samfundets institutionelle struktur. De udvikler ny politik og legitimerer den som væsentlig og relevant.

Ny politik udvikles, når disse aktører træder ind i rollen som policy entrepreneuer og introducerer nye idéer og emner til politik. Diskursen blandt aktørerne tager en koordinerende form, hvor alliancer skabes og ideer forhandles. Alle disse aktører har en privilegeret position, når det handler om at tilvejebringe nye politiske ideer og diskurser og frame dem, så de bliver spiselige for de øvrige deltagere.

Den politiske proces i policy sfæren kan beskrives som et organiseret anarki (Cohen, March \& Olsen 1972). Det betyder blandt andet, at det ikke altid er rationelt, hvilken politik systemet producerer. Outcome og output er mere eller mindre tilfældigt sammenkoblet med løsninger, problemer og politiske stemninger og begivenheder. Er automatisering og digitalisering for eksempel en udfordring (problem) eller en mulighed (løsning) for Danmark? Vælger du som toppolitiker, at det først og fremmest er et problem (måske fordi du har ganske mange vælgere i en disruption-ramt finanssektor), så skal du finde på en løsning. Den behøver ikke være permanent, bare der tager sig ud som et svar ("Disruptionrådet”) på udfordringen.

Løsninger, problemer og politiske stemninger er strømme igennem det politiske system, som altså kobles mere eller mindre vilkårligt gennem politiske begivenheder. Disse begivenheder beskrives som en form for åbne vinduer for nye politiske muligheder. Det er her problem og løsninger kobles. De politiske aktører er afhængige af deres evne til at time budskaber med åbne vinduer. Det handler om at være beredt og klar, når muligheden for indflydelse viser sig. Man kan bare ikke altid vide, hvornår det sker. Et beredskab og viden om, hvordan man bør handle og agere, når et relevant vindue åbner sig, er derfor vigtig. Medieskabte skandaler kan for eksempel være et åbent vindue, hvor der kan stilles krav om øget lovgivning. Sidst men ikke mindst er det vigtigt over tid at kunne påvirke, hvad der egentlig opfattes som problemer og løsninger. Her bliver framing (vinkling) essentiel (Kingdon 2001: 333). Er skat på transport for eksempel en løsning på miljøproblemer eller et problem for retten til fri bevægelighed?

\section{a. Policysferen i Danmark}

I lighed med de skandinaviske lande har Danmark været kendetegnet af et korporativt system, hvor interesseorganisationer deltager i det lovforberedende arbejde i råd, nævn og komitéer. Et 
system, der blev skabt i takt med velfærdsstatens opbygning. Flere studier viser, at dette system ikke har den samme betydning i dag. Denne 'afkorporatisering' begyndte allerede i slutningen af 1970erne. Tendensen har været den samme i de andre skandinaviske lande (Blach-Ørsten, Willig, \& Pedersen, 2017). I stedet for at få indflydelse via faste pladser i råd og nævn må interesseorganisationerne i stedet forsøge at få indflydelse via direkte lobbyisme (Rommetvedt et al., 2012) eller indirekte lobbyisme gennem medierne (Allern \& Pollack, 2012).

I Danmark har det betydet, at der er opstået en særlig gruppe af forskellige, men ressourcestærke organisationer, som har privilegeret adgang til policysfæren, hvor de kan deltage i afgørende politiske beslutninger (blandt dem er LO, DI, og Forbrugerrådet). De har kapacitet til ikke bare at deltage i det 'gamle' korporative system, men også udøve direkte lobbyisme ift. parlament og embedsværk og indirekte via medierne. Disse organisationer repræsenterer stadig trods alt forskellige interesserer, og derfor er styreformen blevet betegnet som 'privilegeret pluralisme' (Binderkrantz et al 2015).

Aagaard \& Blach-Ørsten (2018) argumenterer, at der side om side med denne privilegerede pluralisme er opstået en 'policy professionel stat', hvor en særlig gruppe af veluddannede, medievante og politisk kompetente personer på tværs af de nævnte interesseorganisationer såvel som public affairs-branchen tilvejebringer fagligt input og nye ideer til policysfæren. Denne gruppe blev også identificeret i Magtudredningen fra 2003, hvor den blev omtalt som en voksende gruppe af eksperter på tværs af ministerier, interesseorganisationer, politiske partier, tænketanke m.v. (Togeby, Goul Andersen, Munk Christiansen, Beck Jørgensen, \& Vallgårda, 2003: 99). De befinder sig ifølge Magtudredningen relativt skjult i magtens korridorer, hvorfra de arbejder med dagsordensættelse og påvirkning på tværs af policysfæren og den kommunikative sfære.

\section{Den kommunikative sfære}

Den kommunikative sfære bygger videre på forestillingen om eksistensen af en offentlig sfære. Men det er ikke en offentlig sfære, som den der opstod ved det liberale demokratis fødsel, rundet af et ideal om åbenhed, folkelig deltagelse og oplyst fællesskab. Den kommunikative sfære er kompleks, fragmenteret og til tider ekstremt centraliseret eller semiåben. Aktørerne er mangfoldige: tænketanke, PA-konsulenter, repræsentanter fra organisationers politiske sekretariater, ordførere fra de politiske partier, regeringstalsmænd, politiske kommentatorer, mediepopulister såvel som højt profilerede aktivister fra civilsamfund. De kommunikerer alle for 
at legitimere de institutioner, de er en del af. Andre kommunikerer kritisk for at forandre dem (Schmidt, 2008: 310).

I den kommunikative sfære tager diskursen en mere kommunikativ form, og handler om præsentation og legitimering af de politiske ideer, der blev undfanget i policy sfæren. Kommunikation tager form af informationscirkler på tværs af sociale medier og redaktionelle medier (Chadwick, 2011b), hvor en lang række forskellige politiske aktører indgår i løst koblede interaktioner. Disse cirkler fungerer som arenaer for værdi- og idékampe for samfundsledende aktører, hvor politiske aktører, der enten har adgang til eller forsøger at skaffe sig adgang til policysfæren, forsøger at legitimere deres politiske idéer.

Afhængig af den politiske idé foregår meget af kommunikationen i nichemedier, dagbladsmedier med betalingsmure eller til konferencer, som kræver akkreditering og deltagergebyr. Kommunikationen foregår med andre ord i en form for offentlighed, der er fragmenteret og til tider kun er semi-åben.

\section{a. Den kommunikative sfare i Danmark}

Den kommunikative sfære i Danmark er hjemsted for en lang række organiserede interessers aktiviteter, tænketanke, nichemedier og public affairs virksomheder. Deres tid går med at publicere i netmedier, påvirke beslutningstagere, påvirke redaktionelle medier, konferencer, producere analyser mv. De er alle helt afhængige af at kunne optræde troværdigt, ikke mindst i medierne. Danmark er et højt medialiseret land (dvs. den politiske proces er stærkt præget af medielogik) (Blach-Ørsten, 2016). Medialiseringen af politik betyder, at en række centrale politiske aktører formår at anvende medielogik til at centralisere offentlig fokus og opmærksom omkring sig selv og/eller deres politiske mærkesager. Det er dermed ikke tilfældigt, at politiske emner centreret omkring Slotsholmen får ganske stor dækning i offentligheden, mens f.eks. kommunalpolitik eller EU-politik får relativt lidt (Blach-Ørsten 2016: 212). Dagsordensættelsen skal dog ikke ses som et instrumentelt produkt af de politiske aktørers virke, men ressourcestærke aktører har de bedste betingelser for at påvirke medier og målgrupper i den diskursive kamp, der finder sted i medierne. Mediebegivenheder, som f.eks. skandaler og enkeltsager, bruges derfor strategisk af politikere såvel som embedsværk (Se f.eks. Pedersen \& Aagaard, 2015). 
Som nævnt ovenfor, så tager nyhedsflowet i det hybride mediesystem ind i mellem form af informationscirkler, hvor en lang række forskellige politiske aktører indgår i løst koblede interaktioner i et forsøg på at legitimere deres politiske idéer. Også i det danske mediesystem fungerer disse cirkler som arenaer for værdi- og idékampe for samfundsledende aktører. De fleste politikere og de fleste organiserede interesser er aktive på sociale medier og forsøger samtidigt at påvirke dagsordenen i redaktionelle medier. Vi ved, at der er store forskelle på, hvor aktive, strategiske og dialogorienterede danske politikere er på sociale medier (Sørensen, 2016). Det samme gælder givetvis de organiserede interesser, men forskningen på dette felt begrænser sig til politikernes anvendelse af sociale medier. Så vi ved faktisk ikke, hvor strategiske og dialogorienterede de organiserede interesser er i den kommunikative sfære. Der mangler helt klart empiriske undersøgelser, der i bred forstand kortlægger de organiserede interessers lobbyist- og mediestrategier.

\section{Policy entreprenuerer som samfundsledere}

Policy entreprenuerer er motiverede politiske aktører, der specialiserer sig i at viderebringe politiske ideer, inden for en specifik politisk kontekst (Mintrom \& Norman, 2009; Mintrom \& Vergari, 1996: 422). Det gør de blandt andet ved at skabe netværk og identificere problemer og løsninger og udnytte de 'åbne vinduer' for politiske forandringer, der undertiden opstår i politiske processer (Mintrom \& Norman 2009: 652). Litteraturen har en tendens til at idealisere policy entreprenuerer, som dem, der skaber dynamik og innovation i politiske systemer ved f.eks. at tage store ricisi (ibid:653). Mintrom \& Vergari (1996:423) afviser derfor da også, at lobbyister for særinteresser kan være policy entreprenuerer. Den afvisning bygger imidlertid på en misforståelse af forholdet mellem policy entreprenuership og den givne institutionelle orden. Policy entreprenuerer arbejder for at tilpasse og ændre bestående politikker, men sådanne justeringer kan lige såvel hævdes at føre til stabilisering af den herskende institutionelle orden, som forandring af samme (Schmidt, 2010). Policy entreprenuerer er med andre ord langt fra altid institutionelle entreprenuerer. De kan meget vel ændre den politiske symbolik og praksis, uden at ændre den herskende orden.

For at få adgang til eller fastholde sin adgang til policy sfæren og den kommunikative sfære, så kræver det som mindstemål, at policy entreprenuerer har diskursive evner ("foreground discursive abilities” ifølge Schmidt, 2010), som handler om evnen til at kommunikere kritisk omkring bestående institutioner - enten for at ændre dem eller evne til at bevare dem. Policy 
entreprenuerer skal derudover være i besiddelse af "background ideational ability", som gør dem i stand til at handle i et givent policy-felt, for enten at bevare eller ændre bestående institutioner. Disse 'baggrunds-evner' er stort set synonymt med Bourdieus habitus-begreb (Schmidt 2008:315). Aktøren skal være i besiddelse af en vis position og erfaring for at kunne gøre sig gældende i et givent policy-felt.

I lyset af den ovennævnte litteratur kan vi komme nærmere på et begreb om samfundsledelse. Samfundsledelse er en form for policy entreprenuership, der adskiller sig altså fra den direkte magtudøvelse i det formelle politiske system. Den rummer ingen formel instruks og har ingen juridisk myndighed. Men den kan gøre myndighedsudøvelsen til sit redskab. For samfundsledelse er magtudøvelse, og det kræver vilje, netværk, kompetencer og ressourcer at indgå i spillet om en position som samfundsledende. Samfundsledelse opererer inden for de dimensioner af magtbegrebet, vi kan kalde diskursivt og institutionelt. Dets genstandsfelt er de værdier, normer, ideer og de emner, der på et givent tidspunkt diskuteres i befolkningen. Magtudøvelsen er med andre ord 'blød' fremfor 'hård'. Såvel 'Dovne Robert'-miseren som 'Paradise papers' er diskursive omdrejningspunkter for samfundsledelse, hvor værdier og normer i befolkningsgrupper kan flyttes, og nye ideer kan introduceres. To forskellige tilgange forsøger at beskrive og fange denne form for samfundsledelse i den nuværende institutionelle orden: Det første handler om policy professionelle - og det andet om lobbyister.

\section{a. Policy professionelle}

Policy professionelle er en form for 'policy elite' (Dahl 1961). Selve betegnelsen tilskrives Hugh Heclo (1978: 274), der beskrev fremvæksten af policy professionelle i forbindelse med de organiserede særinteressers indtog i Washington i 1970erne. I nyere litteratur beskrives policy professionelle af Svallfors (2016a: 57) som de ”personer, der er beskæftiget med at påvirke politik og politisk beslutningstagning på steder som regeringskontorer, politiske partier, interesseorganisationer, PR-bureauer og tænketanke.” I Skandinavien er det især i Sverige, at denne form for elite har været være studeret (Garsten, Rothstein, \& Svallfors, 2015; Svallfors, 2016a, 2016b). Policy professionelle har altså stor indflydelse, uden at være valgt til noget embede. De er ansatte, og deres uddannelsesbaggrund minder om embedsmænd i statsadministrationen, men de er på den anden side heller ikke upartiske, for de er ansat til at fremme helt bestemte politiske idéer, interesser og værdier. Som policy professionel skal man evne at sætte en offentlig dagsordensættelse på baggrund af en høj faglig indsigt. Samtidig skal man 
være i besiddelse af et professionelt såvel som personligt netværk, både inden for medieverdenen og i policysfæren (Se boks 1). Netværk, som anvendes til at bringe nye idéer frem til beslutning i policysfæren.

\section{b. Lobbyister}

Lobbyisme kan defineres som kommunikative handlinger, der har til formål at påvirke politiske beslutningstagere (Davidson 2017:1) såvel som den offentlige dagsorden (Aagaard \& BlachØrsten 2018; Binderkrantz \& Pedersen 2017). Relationen mellem lobbyisten og beslutningstageren er som regel uformel og ikke institutionaliseret og står i modsætning til den korporative stats formelle og institutionaliserede relationer (Blach-Ørsten, Willig, \& Hemming Pedersen, 2017; Christiansen \& Rommetvedt, 1999; Rommetvedt et al., 2012: 461). Alligevel tenderer lobbyister mod at blive en essentiel del af den politiske proces (Davidson, 2017: 3). Lobbyisme handler med andre ord om, hvordan særinteresser kan skaffe sig adgang til beslutningstagere såvel som medier. Lobbyisten ansættes ofte i kraft af sit personlige netværk og er afhængig af at vedligeholde sit netværk, ikke mindst ind i policysfæren (Se boks 2). Denne form for lobbyisme kaldes også "direkte lobbyisme" eller 'inside lobbyism'. I en medialiseret tidsalder får lobbyismen dog en ny dimension, hvor det handler om at påvirke beslutningstagere indirekte via medierne ved at skabe omtale omkring en helt bestemt sag (Binderkrantz et al., 2015; Binderkrantz \& Pedersen, 2017; Blach-Ørsten \& Kristensen, 2016; Aagaard \& Blach-Ørsten, 2018). Denne form for lobbyisme kaldes også indirekte lobbyisme, medie-lobbyisme eller 'outside lobbyism'. Et ry som troværdig i forhold til kunder, politikere og embedsværk er helt afgørende for lobbyisten, samtidig med at de skal evne at kommunikere kritisk, både offentligt såvel som i personlige møder, for at fremme kundernes interesser.

\section{Diskussion: Hvem ledes af samfundsledere?}

Lobbyisme og policy professionalisme er vigtige for liberale demokratier. Det er med til at skabe en sammenhæng mellem embedsværk, parlament og regering på den ene side - og resten af samfundet på den anden side. Det kan dæmme op for risikoen for fejl i lovgivningsarbejdet. Analysen ovenfor tegner dog et noget elitært billede af samfundslederskab. Det synes at være særligt privilegerede aktører, der har adgang til policysfæren. Lobbyisme og policy professionalisme er kendetegnet af en ulighed, hvor især økonomisk stærke interesser har mulighed for at sætte sig igennem på bekostning af mindre ressourcestærke og borgernære 
interesser (Binderkrantz \& Pedersen, 2017; Davidson, 2017: 3). Det er her vigtigt at have for øje, at forestillingen om de 'policy professionelle' stammer tilbage fra Heclos artikel i 1978. Hans artikel er en indirekte beskrivelse af udviklingen i det årti, hvor lobbyismen og særinteresserne for alvor flyttede ind i Washington og over den næste generation skabte den sammenblanding af politisk system og organiserede interesser, der i dag er endt med ulighed og mistillid til det amerikanske politiske system. Der er derfor god grund til at spørge, hvilken udvikling samfundslederne er en del af? Og ikke mindst er der grund til at spørge, hvem det egentlig er, at samfundslederne leder? Hvor er borgerne henne i ovenstående analyse af samfundslederskab? Der mangler imidlertid forskning i de organiserede interessers strategier, vi ved derfor heller meget om, hvordan eller i hvilket omfang det lykkes dem at inddrage borgerne i dialog om samfundets udvikling.

Schmidt nævner selv, at hendes teori om diskursiv institutionalisme kan kritiseres for at bygge på en forestilling om et elite-styre, der udvikler ideerne og derefter 'sælger' dem til en bredere offentlighed. Hele hendes pointe med at dele op i to sfærer, er, at diskurser kan forblive koordinerende uden at blive kommunikative. Når diskurser ikke bliver kommunikative, kan det være, fordi de er for teknisk komplekse, men det kan også være, fordi de ikke er legitime i en bredere offentlighed (2008:311). Den samme analytiske betragtning kan man dog også gøre gældende mellem den kommunikative sfære og borgerne. Semioffentligheder såsom konferencer med højt betalingsgebyr, nichemedier med betalingsmure - samt ikke mindst mediernes personliggørelse (Bimber 2014) og borgernes selv-selektering i strømmen af informationer (Zuiderveen Borgesius et al., 2016), som typisk sker på baggrund af interesser, alder og uddannelsesniveau, er alt sammen med til at lukke og skærme dele af den kommunikative sfære fra store segmenter af borgere.

Nu er det ikke sådan, at Schmidt helt ignorerer borgerne (Schmidt 2008:320). Diskurser rummer nemlig også potentialet til kollektiv handling. Diskursive evner er afgørende for, at der kan skabes 'diskursive koalitioner' til fordel for reformer, som går imod interesser, der har forskanset sig i policysfæren (ibid:16) - eller den kommunikative sfære, kunne man tilføje. Så selv om den almene borger ikke ligefrem er koblet direkte til den kommunikative sfære, så kan man heller ikke ligefrem reducere dem til tilskuere. Spørgsmålet er dog, om man ligefrem kan sige, at der også findes en borgersfære? 
Borgere kan indimellem få en trang til at protestere. Bennett \& Segerberg (2012) beskriver således muligheden for almene borgeres mere personliggjorte former for deltagelse i protestbevægelser via sociale medier. Disse bevægelser kan skaleres hurtigt op, er mere fleksible, når det handler om at forfølge politiske mål i forandring og bygge bro over forskellige emner (ibid: 742). Disse netværk bygger på en særlig logik af forbundet handling, som i Bennett \& Segerbergs optik afløser gamle, mere formelle måder at organisere sig på. De har ikke behov for høj grad af central kontrol eller en stærk fælles kollektiv identitet. Dermed er der tale om et skifte mod en mere flydende form for politisk deltagelse, centreret omkring emnespecifikke grupper (Carty, 201 1: 17; Se også Chadwick, 201 1b: 6-7). \#Metoo og \#menext-bevægelserne er gode eksempler på sådanne tiltag. Disse bevægelser skaber et fornyet håb om, at sociale medier kan medføre demokratisering i form af tilgængelighed, åbenhed, oplysning, mulighed for mere interaktivitet og synkrone (tovejs) relationer mellem brugerne, samt mulighed for at motivere til deltagelse i demokratiet på tværs af sociale skel (Carty, 2011: 4 \& 16; Jensen, 2016: 266; Klinger \& Svensson, 2015: 242; Sørensen, 2016: 665).

Det håb er desværre tidligere blevet skuffet. Siden 90erne har der været store forventninger til, hvad bevægelser som ATTAC (1998) og 'Occupy Wall Street'(2011) såvel som de folkelige opstande i det arabiske forår (2010-11) kunne gøre med den nye teknologi. I dag er forventningerne noget mere afdæmpede og realistiske (Se f.eks. Dahlgren, 2005; Nielsen, 2011; Norris, 2002: 10). Selv når disse bevægelser går offline og deltager i aktiviteter, der synes at kendetegne et nyt deliberativt demokrati, såsom folkemøder, studiekredse og frivillighed, så viser de empiriske studier af disse 'mini-offentligheder', at der er en klar sammenhæng mellem deltagelse, uddannelse og socio-økonomisk status. (Davidson 2017: 6). Der prædikes med andre ord for de indviede.

Budskabet på borgernes vegne er derfor alt i alt en smule negativt: De kan selv-selektere i strømmen af information eller de kan protestere. De får sjældent adgang til policy-sfæren, fordi det kræver store ressourcer, såvel som organisatoriske og diskursive evner, hvor man formår at kommunikere professionelt. De får ofte kun indflydelse via protestvalg. De får også kun lejlighedsvist adgang til den kommunikative sfære, og i det omfang de gør, er det kun i kraft af et aktivistisk engagement offline for de ressourcestærke eller via et traditionelt, formelt organisatorisk engagement nederst i en frivillig forenings eller fagforenings hierarki. En egentlig borgersfære har derfor endnu ikke manifesteret sig. 


\section{Findes der en gryende borgersfære i Danmark?}

Allerede den danske magtudredning i 2003 gjorde opmærksom på eliternes indflydelse i Danmark (Togeby et al 2003). Togeby m.fl. (2003: 241) fastslog samtidig, at landet ikke rummer én, men flere eliter, der er mere eller mindre uafhængige af hinanden. Dermed bestod pluralismen (og dermed demokratiet) på tværs af samfundet på trods af eliternes indflydelse, ifølge Magtudredningen. Spørgsmålet er, om det har ændret sig, og om der ikke er opstået en grad af gensidig afhængighed mellem de forskellige danske eliter, så de ikke længere fastholder den nødvendige distance til hinanden? I følge Grau Larsen et al (2016) består eliternes elite (elitenetværket, ifølge forfatterne) i dag af 423 danskere, som adskiller sig markant fra resten af befolkningen, når det gælder kønssammensætning, social baggrund, uddannelse, karriere og bopæl (typisk lige nord for København). Det er mennesker, der interagerer i alle mulige formelle og uformelle sammenhænge, fra konferencer til VL-grupper. I forfatternes optik er pluralismen dermed død. Spørgsmålet er dog, om det er gået helt så galt.

Eliternes elite gør det ganske vist ikke ligefrem nemt for borgerne at deltage. Ifølge Magtudredningen fra 2003 var der egentlig en stor åbenhed og mulighed for indsigt i eliternes politiske ledelse. Offentlighedsloven fra 2013 giver dog i dag myndighederne mulighed for at hindre indsigt i dokumenter, som anvendes i embedsværkets rådgivning af en minister. Det er dokumenter, som på væsentlige områder ofte bliver til i samarbejde med organiserede interesser. Offentlighedsloven giver også mulighed for at hindre indsigt i ministres kalender samt dokumenter udvekslet mellem myndigheder, ministerier og medlemmer af Folketinget. Ifølge Folketingets ombudsmand har loven væsentligt indskrænket offentlighedens mulighed for aktindsigt. Dermed reducerer loven borgernes mulighed for indsigt og bidrager til, at policysfæren lukker sig mere om sig selv.

I Danmark har mediesystemet bevæget sig fra at være domineret af elektroniske massemedier til et hybridt mediesystem, hvor redaktionelle medier som aviser, radio og tv i stigende grad digitaliseres og udbydes til nichepublikum frem for massepublikum, samtidig med at de interagerer og kombineres med sociale medier. Det danske mediesystem med stærke elementer af public service og få store, landsdækkende dagblade, er derfor i færd med en heftig transformation, som påvirker borgernes mulighed for at få indsigt og indflydelse på den kommunikative sfære og policysfæren. Det store flertal af danskerne stadig bruger redaktionelle nyhedsmedier, men vi ved fra medieundersøgelser, at danskerne kun i begrænset omfang bruger sociale medier til politisk 
dialog (Schrøder \& Nielsen, 2014). Sociale medier er ikke ligefrem noget der ansporer, danskerne til aktivisme i nævneværdigt omfang. Borgerne overtager i vidt omfang mediernes rammesætning og opfattelse af politik, som noget der foregår på Slotsholmen og eventuelt i det kommunale byråd. Lidt bedre er det med den politiske mobilisering, hvor knap halvdelen af alle danskere har deltaget i en eller anden form for aktivitet (underskriftsindsamling eller har fulgt en politiker). Dette indtryk bekræftes af Kulturstyrelsens rapport om brugen af sociale medier fra 2015. Alt i alt tegner denne forskning altså et meget traditionelt billede af borgerne, som relativt passive tilskuere til den politiske kommunikation.

Vi ved også, at en tredjedel af befolkningen forsøger helt at undgå nyhedsstof i det hele taget, fordi det gør dem i dårligt humør, eller fordi de ikke har tillid til, at nyhedsmedierne er troværdige (Schrøder, Blach-Ørsten, \& Burkal, 2017). Fravalget af nyheder er stigende. Thorningregeringens Public Service-udvalg konkluderede i 2016, at: ”De medier, der mest direkte understøtter dansk demokrati og kultur (dagblade på print og web, nye netmedier og public service-medier), må i [de næste 10 år $]$ antages at ville lægge beslag på en stadig mindre del af befolkningens tid. Dermed vil deres funktion som modvægt til et kommercielt (og udenlandsk) medieudbud svækkes" (Kulturministeriet, 2016: 13).

Det hybride mediesystem gør det vanskeligere for borgerne at deltage på et oplyst grundlag. 80 procent af internettrafikken varetages i dag af store globale tech-virksomheder som Google og Facebook. Det har sat danske medier, herunder public service, under stigende pres, således at: "danske medievirksomheder i 2017 i markant grad ikke længere selv har kapacitet til at definere de teknologiske, distributionsmæssige eller forretningsmæssige standarder, de benytter sig af, når de leverer dansk indhold til de danske mediebrugere." (Kulturstyrelsen, 2017: 5). Google og Facebook har et tiltagende duopol i det danske mediesystem. Konsekvenserne af det kan være mangfoldige: en stigende kommercialisering, svækket troværdighed omkring danske mediebrands og en svækket journalistisk diversitet, samt en svækkelse af mediernes rolle som demokratiets vagthund i kraft af en mangel på ressourcer til dybdeborende journalistik. Det er en udvikling, der er i færd med yderligere svække almindelige borgeres mulighed for at få indsigt i og indflydelse på, ikke bare aktørerne i policysfæren, men også de organiserede interesser i den kommunikative sfære. Alt i alt tyder det på, at der er et stigende behov for, at samfundslederskab mobiliserer borgerne. 


\section{Hvem mobiliserer borgerne?}

Hvem forsøger at mobilisere borgerne i liberale demokratier i dag? Det gør selvfølgelig en lang række af de organiserede interesser også, så som fagforeninger, forbrugerorganisationer og frivillige foreninger. Men ikke alle er lige borgernære. Mange af de organiserede interesser, der voksede ud af borgerbevægelser, arbejder i dag for at sikre sig direkte adgang til policy sfæren. Men nogle arbejder til dels også borgernært. Hvordan gør de så det, og gør de noget, der er anderledes end det de økonomisk stærke interesser gør? Kan de ligefrem komme til at optræde i rollen som policy entrepreneurer på linje med policy professionelle og lobbyister? Binderkrantz og Pedersen (2017) argumenterer for, at der er forskelle mellem økonomiske og borgernære interesser, men forskellene handler ikke kun om ressourcer, men også om valg af strategi. Økonomiske interesser vælger typisk en inside-strategi og søger at påvirke beslutningstagerne direkte. Borgernære interesser vælger typisk en outside-strategi og søger i stedet at påvirke den offentlige dagsorden. Det kan lyde mere vagt, men over tid kan dagsordensættelse have stor betydning for det beslutningsrum, politikerne har. Som det fremgår tekstbokse 3 og 4 kan 'over tid' dække over en livslangt engagement.

Der er særligt to typer af litteratur, der omhandler aktører, der forsøger at mobilisere borgere. Den ene handler om aktivisme og den anden om populisme.

\section{a. Aktivister}

Aktivister er drevet af retfærdige og moralske sager. Anerkendelse og rettigheder, herunder konkrete ændringer i lovgivning og støtteordninger er typisk målet for aktivister. I en tid med medialiseret politik kan fremvæksten af sociale medier som tidligere nævnt skabe medinddragelse af borgere. Borgerne kan selv publicere, producere og vidensdele, ideelt set som en slags nonprofit borger-journalister, bloggere eller lokale medieaktivister (Hoff-Clausen, 2009: 496 \& 483), hvormed de kan blive del af mere eller mindre selvorganiserede netværk (Bennett \& Segerberg, 2012; Chadwick, 2011a) (se ovenfor). Borgere kan altså indtage rollen som ledende aktivister, hvis og såfremt deres aktivisme giver dem en central position i et af disse selvorganiserede netværk. Det kræver dog givetvis professionel kompetence - og måske også en hvis portion held - at ende i en central position i sådanne netværk. En evne til politisk kommunikation, den rette historik og habitus med en personlig historie, som grupper af borgere kan identificere sig med, er ofte afgørende for ledende aktivisters troværdighed (Se boks 3). 


\section{b. Populister}

Populisme er ikke et nyt fænomen i den vestlige verden. Det har været en del af liberale demokratier siden 1970erne, i kølvandet på oliekriserne. Der er ovenikøbet en del, der tyder på, at populisme er blevet mainstream (Mudde, 2004: 542). En væsentlig årsag til det er medialiseringen af liberale demokratier. Medialiseret politik, hvor der ofte fokuseres på skandaler og personer, er den perfekte scene for populister. Samtidig er populister ofte perfekte kilder for sensationsjagende journalister (Mudde, 2004: 553; Aalberg, Esser, Reinemann, Strömbäck, \& de Vreese, 2016: 3). Populisme bliver hermed " a political communication style of political actors that refers to the people.” (Jagers \& Walgrave, 2007: 322). Populisme handler dermed først og fremmest om italesættelse af og evne til at appellere til 'folket'. Dertil kommer en underliggende forståelse af, at 'folket' er uforeneligt med 'eliten' (Mudde 2004: 543), og til tider uforenligt med udvalgte grupper i befolkningen, som f.eks. etniske eller religiøse mindretal (Jagers \& Walgrave 2007). Yderligere er der gode argumenter for, at 'systemet' eller modstand mod 'systemet' også er en hyppigt anvendt diskursiv trope for populister. I Danmark kendes det f.eks. fra Mogens Glistrups opgør med skattesystemet. Populisten skal altså evne at kommunikere, som om de er 'folkedybets' eller 'det tavse flertals' naturlige repræsentant. Dernæst skal de også evne at formulere kritik og krav til, hvordan bestående institutioner skal forandres, så de bliver mindre elitære.

I en medietid er populisten som type altså ikke bundet til en bestemt politisk fløj (Mudde 2004: 551; Aalberg et al 2016:6). De finder deres eksistensberettigelse i netop den tendens til elite-styre, der er indbygget i policy sfæren. Populisme bliver dermed en konsekvens af elite-styre helt på linje med lobbyisme og policy professionalisme. Det er en rolle eller en (medie)strategi, aktører kan forfølge for at få indflydelse. Det er altså ikke kun politikere, der kan optræde i rollen som populister, men også ledere af bevægelser, interesseorganisationer eller journalister (Jagers \& Walgrave 2007: 322).

Det kan klart diskuteres, hvorvidt aktivister og populister kan gøre krav på en position som samfundsledende. De har sjældent direkte adgang til policysfæren, men policysfæren er som nævnt heller ikke deres arena. Mens lobbyister og policy professionelle typisk vælger at påvirke beslutningstagere mere direkte, så vælger populister og aktivister at arbejde mere borgernært og mere langsigtet med dagsordensættelse. Det er klart et empirisk spørgsmål, hvorvidt at deres bestræbelser lykkedes. 
I mangel af bedre kan vi måle lobbyisternes og de policy professionelles indflydelse på penge. Dygtige lobbyister har nemlig sponsorer, mens dygtige policy professionelle bliver ansat af stærke interesseorganisationer. Her er det noget sværere at måle populisters og aktivisters indflydelse, men det kan eventuelt være en god idé at måle dem på deres evne til dagsordenssættelse. Måske endda på deres 'reach' (hvor mange brugere når de) og deres 'traction' (hvor godt har de fat i dem, de når) på sociale medier.

\section{F. Konklusioner og fremtidig forskning}

Samfundslederskab er en form for policy entreprenuership, hvor aktøren ikke har noget formelt mandat. Uden formel magt er evnen til at kommunikere politisk i forskellige fora og medier helt afgørende. Samfundslederes magt er derfor diskursiv. Uden diskursive evner, intet lederskab. Deres styrke er evnen til at dagsordensætte - samt søge en position, hvorfra de kan forme værdier, normer og politiske ideer. Styrken ligger dermed i evnen til at overbevise eliternes elite, eventuel via et langvarigt skub til folkeopinionen.

Det fremgår af analysen, at lobbyister og policy professionelle udfører samfundslederskab. Spørgsmålet er, om der også findes andre og mere borgerrettede former for samfundslederskab? Aktivister og populister kunne være oplagte bud, men der mangler forskning, der viser, hvorvidt diskursivt kapable og velorganiserede aktivister og populister har indflydelse på linje med samfundsledende lobbyister og policy professionelle. Der er forsket ganske lidt i deres strategier og indflydelse som en del af et medialiseret, liberalt demokrati.

Aktivister og populister kan inddrage borgere i nye, løst koblede folkebevægelser og kampagner via sociale medier. I lyset af resultaterne fra de medieundersøgelser, der refereres ovenfor, lader det dog ikke til, at denne form for inddragelse er fremtrædende i Danmark. Befolkningen lader til at være relativt passive tilskuere til de politiske processer. Forklaringen kan selvfølgelig også være, at bestræbelserne ikke fanges af disse medieundersøgelser. Måske foregår borgernært samfundslederskab primært i andre fora end den mediearena, som forskningen ellers antager er så vigtig. Måske er det snarere konferencer, folkemøder, forsamlingshus-aktiviteter og kantinemøder på virksomheder, der er fora for borgernært samfundslederskab.

Skema 1 opsummerer de fire nævnte roller. Det skal understreges, at der ikke er tale om en typologi i traditionel forstand, hvor typerne gensidigt udelukker hinanden. De fire roller skal 
snarere anskues som relativt flydende. Det fremgår også af de fire eksempler (bokse 1-4). Barfoeds og Jespersens biografier viser, at der kan være et liv som samfundsleder efter karrieren som folketingspolitiker. Folketinget kan måske endda bruges til at bygge et personligt brand og en position som samfundsledende. En konkret aktør er altså ikke låst fast til en rolle, men en bestemt rolle kan alligevel klæbe sporafhængigt til konkrete aktører. Dernæst kan rollerne kombineres i hybrider. Rollerne skal med andre ord ikke betragtes som formelle eller stærkt institutionaliserede, men er i stedet relativt fleksible.

De fire aktører har alle også en organisatorisk base, i form af forening, fond, social entrepreneuer, tænketank, medie mv. som ikke indgår i det formelle politiske system i liberale demokratier.

Denne form for organisatorisk base spiller givetvis en rolle i medialiseret politik, men hvordan eller hvordan de skabes, har forskningen i dag intet bud på.

\section{Skema 1: Oversigt over potentielle samfundsledere}

\begin{tabular}{|c|c|c|c|c|}
\hline Identitet/rolle & Populister & Lobbyister & Aktivister & Policy professionelle \\
\hline Diskursive troper & $\begin{array}{l}\text { Folket, anti-elite, } \\
\text { nationen, brug af } \\
\text { syndebukke, anti-system }\end{array}$ & $\begin{array}{l}\text { For nationens, } \\
\text { velfærdens eller } \\
\text { almenvellets skyld }\end{array}$ & $\begin{array}{l}\text { Retfærdighed, moral, } \\
\text { åbenhed }\end{array}$ & $\begin{array}{l}\text { Faglighed, evidens, } \\
\text { ekspertise }\end{array}$ \\
\hline Orientering & $\begin{array}{l}\text { Idé- og } \\
\text { konfliktorienteret }\end{array}$ & $\begin{array}{l}\text { Fagligt og } \\
\text { sagsorienteret }\end{array}$ & $\begin{array}{l}\text { Sags- og } \\
\text { værdiorienteret }\end{array}$ & $\begin{array}{l}\text { Idé- og } \\
\text { tilpasningsorienteret }\end{array}$ \\
\hline Strategi & Outside lobbyisme & Inside lobbyisme & Outside lobbyisme & Inside lobbyisme \\
\hline Habitus & $\begin{array}{l}\text { Evne til at tilegne sig en } \\
\text { position som } \\
\text { 'folkedybets' } \\
\text { repræsentant }\end{array}$ & $\begin{array}{l}\text { Evne til at tilegne } \\
\text { sig en position som } \\
\text { en troværdig } \\
\text { samarbejdspartner } \\
\text { for både kunder, } \\
\text { politikere og } \\
\text { embedsværk }\end{array}$ & $\begin{array}{l}\text { Evne til at tilegne sig } \\
\text { en position som } \\
\text { talsperson for } \\
\text { borgernes retfærdige } \\
\text { og moralske sag } \\
\text { (advocacy) }\end{array}$ & $\begin{array}{l}\text { Evnen til at tilegne sig } \\
\text { en position, der både } \\
\text { rummer netværk ind i } \\
\text { policysfære, samt } \\
\text { anerkendelse for } \\
\text { politisk ekspertise og } \\
\text { dagsordensættelse }\end{array}$ \\
\hline Diskursive evner & $\begin{array}{l}\text { Evne til at } \\
\text { kommunikere kritisk for } \\
\text { at ændre bestående } \\
\text { institutioner, så de } \\
\text { imødekommer 'folkets' } \\
\text { vilje' }\end{array}$ & $\begin{array}{l}\text { Evne til at } \\
\text { kommunikere kritisk } \\
\text { for at fremme } \\
\text { særinteresser, både } \\
\text { for at ændre/bevare } \\
\text { institutioner }\end{array}$ & $\begin{array}{l}\text { Evne til at } \\
\text { kommunikere kritisk } \\
\text { for at ændre bestående } \\
\text { institutioner, så de } \\
\text { bliver mere eller } \\
\text { forbliver retfærdige og } \\
\text { åbne }\end{array}$ & $\begin{array}{l}\text { Evne til at } \\
\text { kommunikere med høj } \\
\text { faglighed, både for at } \\
\text { tilpasse eller bevare } \\
\text { bestående } \\
\text { institutioner. }\end{array}$ \\
\hline
\end{tabular}




\section{Specialisering af samfundslederskab}

Ud over forskelle i habitus og organisationsformer så har de fire aktører heller ikke den samme appel til borgerne eller samme grad af faglighed i deres argumenter. Der er med andre ord forskelle på, hvilke diskursive evner der kræves, alt efter hvem aktøren vil have i tale. Det indikerer, at de fire nævnte aktørtyper kan placeres i en matrix (figur 1), hvor deres position er bestemt af strategi (inside/outside) (x-akse) og mål (specifik sag vs mere generelle og abstrakte politiske ideer) (y-akse). Denne inddeling kan ses som en form for specialisering inden for samfundslederskab. Nogle er bedre til at appellere til borgerne, andre er bedre til at kommunikere fagligt med eliternes elite i policy-sfæren.

Hverken skema 1 eller figur 1 er udtømmende, men skal snarere ses som et muligt bud på, hvordan samfundslederskab kan struktureres. Der findes også andre aktører uden formelt mandat, som påvirker politik. Det kan f.eks. være højt profilerede intellektuelle og topeksperter. Dernæst skal man selvfølgelig heller ikke afskrive den indflydelse på policy processen, som partiernes politiske ordførere og ministre med formelt mandat fortsat har.

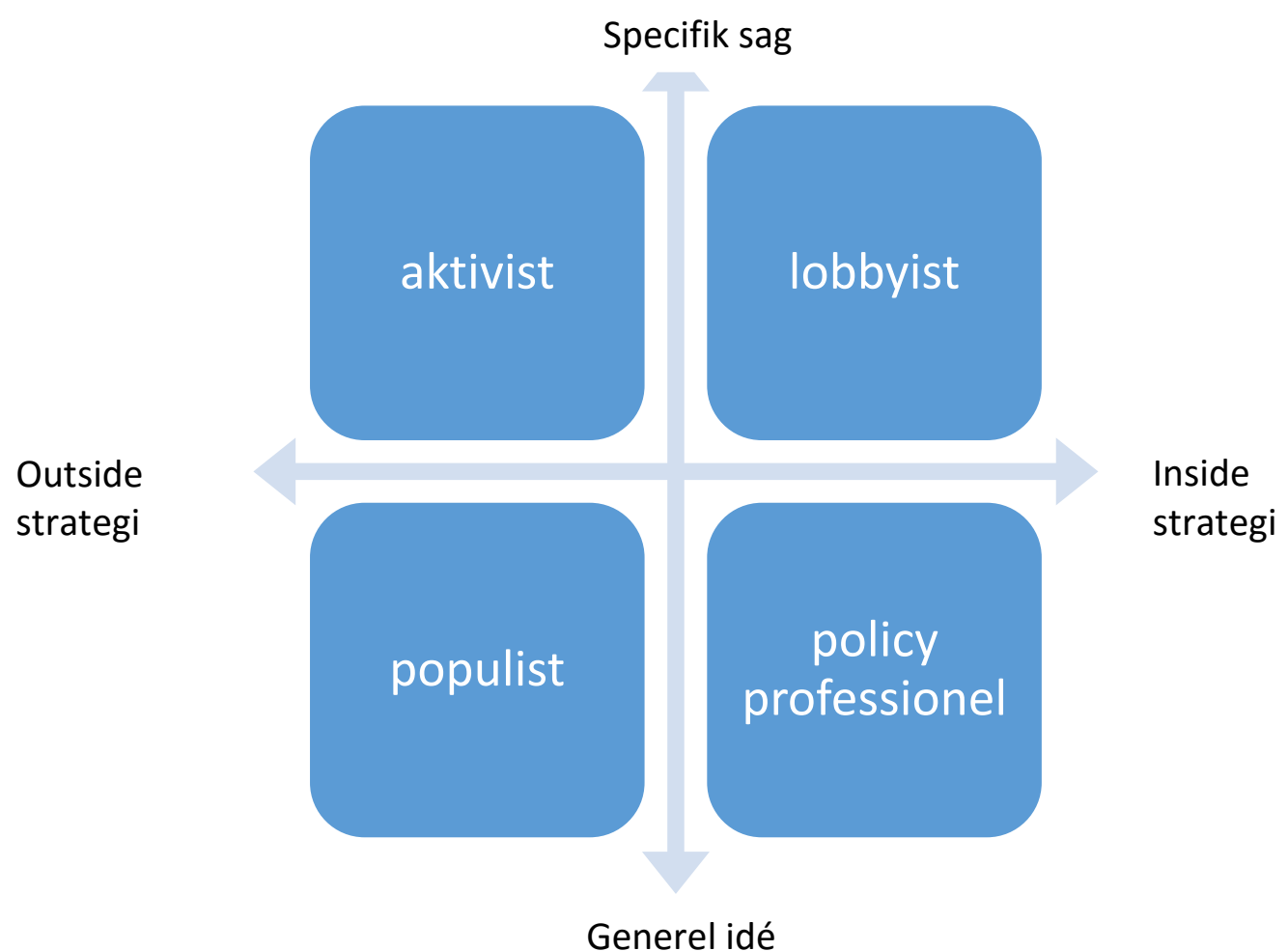

Figur 1: Specialisering inden for samfundslederskab: 


\section{Generalisering: Den danske case}

Artiklen har primært beskæftiget sig med danske forhold. Spørgsmålet er derfor, om danske forhold for samfundslederskab kan betragtes som paradigmatisk case (Flyvbjerg, 1991). Det vil sige, om danske forhold kan anvendes som metafor for samfundslederskab i andre, tilsvarende lande? Vestlige, liberale demokratier er generelt udfordrede i disse år, og trods et højt niveau af tillid, velstand og lighed går Danmark ikke fri af denne udvikling. Også Danmark er udfordret, når det gælder stigende ulighed og vælgerskepsis. I 1990 var Gini-koefficienten på 22,16. I 2016 lå den på 29,01. Mistilliden til politikerne stigende. Ifølge Jørgen Goul Andersen er forklaringerne på faldet i tilliden til de danske politikere efterdønningerne af finanskrisen, utilfredshed med den førte politik og en generel social utryghed (Goul Andersen, 2016: 279). Danmark er altså ikke isoleret fra den globale udvikling eller unik lige på disse punkter. Forskellen er dog, at Danmark kommer fra et meget højt niveau i indkomstlighed og generel samfundsmæssig tillid. Her giver det altså større mening at sammenligne Danmark med de andre skandinaviske lande. I lighed med Danmark er de øvrige skandinaviske lande højt medialiserede, liberale demokratier med hybride mediesystemer. Vi ved også, at tendensen til, at organiserede interesser søger indflydelse gennem lobbyisme fremfor gennem det korporative system, har været den samme i de skandinaviske lande (Garsten \& Sörbom, 2017; Rommetvedt et al., 2012). I den forstand vil vi kunne finde de samme typer af samfundslederskab og lignende betingelser i de andre skandinaviske lande. Her fungerer danske forhold bedre som paradigmatisk case.

Der er dog også forskelle. Ifølge Eurobarometer er der forskelle på henholdsvis Sverige og Finland på den ene side, og Danmark på den anden, når det handler om tilliden til den politiske klasse. Der har ganske vist været vigende tillid til nationale regeringer i både Sverige, Finland og Danmark, men der har været en svagt stigende tillid til de nationale parlamenter i Sverige, Finland - men ikke i Danmark, hvor tendensen siden 2006 har været vigende tillid til Folketinget. Når det gælder de politiske partier, så er der ganske vist en markant mistillid i både Sverige og Finland, men alligevel viser Eurobarometer en vag tendens til forbedring af tilliden til de politiske partier i disse to lande. Det er ikke umiddelbart til at sige, hvad denne forskel skyldes. Muligvis placerer Danmark sig i mellem et generelt højere skandinavisk niveau og et generelt lavere europæisk niveau, når det gælder mistilliden til den politiske klasse. Fremtidig komparativ forskning kunne undersøge om denne forskel i politisk tillid påvirker status for samfundslederskab. Når tilliden til politikerne daler, søger borgernes efterspørgsel på lederskab 
antageligvis andre steder hen. Spørgsmålet er, om det modsatte også er tilfældet, når tilliden til politikerne stiger igen.

\section{Liberale demokratier i krise}

Spørgsmålet om politisk tillid er afledt af et andet og dybere spørgsmål, nemlig om det samfundslederskab, der beskrives her, er et relevant svar på liberale demokratiers aktuelle udfordringer? Eller er det lige omvendt: At samfundslederskab er et symptom på demokratikrisen og dermed en del af problemet?

Når tilliden til politikerne daler, så søger borgernes efterspørgsel på lederskab som nævnt antageligvis andre steder hen. I den forstand kunne samfundslederskab godt være et symptom på det repræsentative demokratis krise. Det gælder ikke kun populister, men også lobbyister og policy professionelle. Når samfundsledere har magt uden mandat, kan man med rette altid spørge: Hvem repræsenterer de andre end dem, der betaler deres budgetter? Og i det omfang de anvender medie som strategi, er de så andet end blot professionelle 'mediedarlings'? Altså, en gruppe af kommentatorer, som lever af - og i pagt med medierne, hvor de er parat til levere en kommentar på stort set hvad som helst.

Svarene på disse spørgsmål er ikke kun teoretiske, men også empiriske og må bero på aktørernes aktiviteter i øvrigt: Hvem mødes de med og under hvilke omstændigheder? Hvem inddrager de, hvordan og hvornår? Her mangler der helt klart forskning. Det vil dog være forkert at underkende den indflydelse, især lobbyister og policy professionelle har. Hvis ikke de havde indflydelse, ville særinteresserne næppe investere i dem. Faktisk tyder meget på, at særinteresserne investerer mere i dem i disse år (Garsten \& Sörbom, 2017). Vi ved dog ikke, i hvilket omfang at det samme er tilfældet i Danmark, og hvorvidt at markedet for interessevaretagelse er i vækst i Danmark. Her mangler også forskning.

Spørgsmålet er dog også, om de samfundsledende aktører, trods alle de nævnte forbehold, også kan være en del af løsningen? Der er næppe tvivl om, at samfundsledere bibringer information og en idérigdom, som det formelle politiske system slet ikke kan undvære og ikke selv kan levere. Det er dog ikke altid lige til at gennemskue, hvorvidt de ideer der får opbakning i policysfæren, så er udtryk for systemforandring til det bedre eller systembevaring. 
Alt i alt mangler vi altså stor viden om denne gruppe. Vi mangler viden om deres adfærd, deres organisationer og deres relationer til eliternes elite såvel som til borgerne. Har de en demokratisk rolle og et ansvar? Og er det et ansvar, de tager på sig? Er de lydhøre og etisk orienteret over for en bredere offentlighed? (Aagaard, 2016).

Hvis samfundsledere har en demokratisk rolle at spille, så er det væsentligt også at diskutere, hvad det er for et demokrati, vi taler om? Hvad er demokrati i et højt professionaliseret og medialiseret vidensamfund? Hvad er det, som samfundsledere eventuelt kan gøre, som kan supplere og eventuelt forny det formelle, repræsentative demokrati? Hvad er det for en form for diskursivt demokrati og offentlighed, der ideelt set skal til? Disse spørgsmål angår ikke mindst den manglende eksistens af en egentlig borgersfære, også i skandinaviske liberale demokratier. Måske er denne manglende borgersfære i sig selv en væsentlig del af årsagen til liberale demokratiers krise. Hvilke institutionelle rammer bør den i givet fald have, så borgerne oplever inddragelse og repræsentation af responsive samfundsledere?

\section{Appendix}

\section{Boks 1: Den danske policy professionelle}

Den policy professionelle færdes som regel ikke i mediernes forgrund, men snarere i eliternes andet geled. Det kan derfor være vanskeligt at finde et velkendt, illustrativt eksempel. Trods den høje medieeksponering kan Peter Mogensen dog på mange måder siges at være et oplagt eksempel på en policy professionel. Mogensen er uddannet økonom. I 90erne fik han adgang til policy-sfæren, først som ministersekretær for finansminister Mogens Lykketoft (1995-1997), siden som politisk rådgiver for statsminister Poul Nyrup Rasmussen (1997-2000). Om sin tid på Slotsholmen har han tidligere udtalt: ”Jeg fik en meget klar fornemmelse for det politiske spil via mine to år som ministersekretær i Finansministeriet og ikke mindst mine tre år som sekretariatschef i Statsministeriet. Jeg var tæt på statsministeren, og min vurdering blev i mange sammenhænge efterspurgt. Det bruger jeg meget i dag. Jeg forsøger at tænke på, hvordan de nu ser situationen og løsningen af problemerne i Statsministeriet og Finansministeriet. Det satte mig i stand til at vurdere, hvordan politikerne tænker. Det gør, at jeg i dag er i stand til at forudsige nogle mulige udfaldsrum," (DJØF-bladet 29.11.07). Efter at have været tæet forbundet med den politiske elite i 90erne skiftede Mogensen til medieeliten i ooerne, som redaktionschef og kommentar på Politiken og TV2 News. I 2011 investerede han både kompetencer og netværk i 
tænketanken Kraka. Ifølge tænketankens hjemmeside er missionen at tilvejebringe og formidle viden, der kan medvirke til at balancere hensyn og politiske beslutninger. Fagøkonomisk analyse er derfor en væsentlig del af Krakas ydelser. Kraka profilerer sig som partipolitisk uafhængig, men helt uafhængig af erhvervseliten kan tænketanken ikke siges at være. Oprindeligt blev Kraka startet i samarbejde med Politiken, Landbrug og Fødevarer og Falck. Kraka støttes i dag også af DI, Dansk Byggeri, Deloitte, Dreyers Fond, IDA, Maersk og Realdania. LO var med i en indledende fase, men valgte at trække sig, netop på grund af spørgsmålet om Krakas uafhængighed (Politiken 08.08.2011).

\section{Boks 2: Den danske lobbyist}

Den tidligere vicestatsminister Lars Barfoed arbejder i dag som lobbyist. Han har altid søgt indflydelsen. Det begyndte allerede som ung jurist i Det konservative folkepartis Christiansborgsekretariat i 80erne. Inden han blev valgt ind i Folketinget i 2001, havde han en erhvervskarriere, blandt andet som direktør i interesseorganisationen Finansrådet. Også i politik havde han skiftende ministerposter frem til valget i 2011 . Han havde en kort periode som partiformand for De konservative 2011-14. Dernæst startede han som lobbyist i firmaet Communique i 2015, og blev siden hen direktør for Public affairs i Prime Time Kommunikation i 2017. Til Altinget udtalte han i 2015 om sit skifte: "Jeg har gennem årene opnået en solid indsigt i de politiske beslutningsprocesser, såvel nationalt som i EU. Samtidig har jeg opbygget et godt og stærkt netværk i både dansk erhvervsliv og blandt de politiske beslutningstagere. Den erfaring og kompetence får jeg nu mulighed for at trække på.” (Altinget 01.10.15). Andre fremtrædende politikere har taget samme karrierevej. En opgørelse viser, at 21 politikere i de senere år har fundet ansættelse i PA-branchen (Blach-Ørsten et al, 2017a og 2017b). Selv om Lars Barfoed har forladt Folketinget, kan man ikke ligefrem sige, at han har forladt policysfæren. Han var stadig statsrevisor frem til oktober 2016. I 2017 blev han formand for Energinet, under Energi- og Klimaministeriet.

\section{Boks 3: Den danske aktivist}

Lisbeth Zornig er højt profileret socialpolitisk aktivist. Hun er uddannet cand.polit. og har arbejdet for Codan, Danske Bank, KMD og IT-firmaet "Specialisterne”. Som tidligere formand for Børnerådet har hun begået sig som leder i NGO-verdenen. I dag omtaler hun sig selv som social entreprenør. Hun er stifter af den sociale tænketank SIF (Social Innovations Forum), stifter af Børnenes IT-fond, initiativtager til demokratikampagnen ”Stemmer på kanten” i 2013, samt stifter 
af Huset Zornig, der efter eget udsagn arbejder på at forny og forbedre indsatsen over for samfundets socialt mest udsatte mennesker. Prisbelønnede dokumentarprogrammer som ”En barndom i helvede” (DR 2012) og "De brændte børn” (TV2 2015) har været helt afgørende for Zornigs position som aktivist med folkelig appel. I disse programmer præsenteres Zornig som en mønsterbryder med en barndom præget af misbrug og institutionsanbringelse. Hun har tidligere udtalt: ”Jeg anser mig selv for et sandhedsvidne, der er født af og opvokset i underklasseDanmark” (Berlingske 2.7.12). Hendes evne til at håndtere medierne var til stor nytte, da hun og hendes mand i 2016 blev i dømt bødestraf for menneskesmugling, fordi de havde givet en syrisk familie et lift. Dommen vakte international opsigt og satte fokus på den stramme, danske udlændingepolitik.

\section{Boks 4: Den danske populist}

Karen Jespersen har sammen med sin mand Ralf Pittelkow tidligere haft privilegeret adgang til policy-sfæren. Pittelkow var rådgiver for statsminister Poul Nyrup Rasmussen, mens Jespersen var socialdemokratisk socialminister og siden indenrigsminister fra 1993-2001. Siden skiftede hun parti, blev medlem af Venstre og var Anders Fogh Rasmussens velfærdsminister fra 2007-2009. Herefter var hun frem til valget i 2011 formand for Udvalget for Udlændinge- og Integrationspolitik. De kommunikative evner har Jespersen ikke mindst erhvervet via en karriere som journalist, blandt andet på TV-avisen. Jespersen har i egen optik gjort sig til talsmand for 'den lille mands stemme'. En position, der i dag opdyrkes via det højreorienterede netmedie Den korte Avis, drevet i samarbejde med Pittelkow. Formålet er at sætte kritisk fokus på indvandring og multikulturelt samfund. Den Korte Avis bliver hyppigt delt på de sociale medier, og synspunkterne på udlændingepolitikken hørt langt ind i policysfæren (jf. finanslovsforhandlingerne 2017). Det kan umiddelbart se ud, som om Jespersen dermed har formået at udføre et markant hamskifte fra elite til anti-elite. Opgøret med politisk korrekthed og humanistisk indvandringspolitik tog hun dog allerede i 90erne som socialdemokrat. Med Den korte Avis har hun dermed blot fuldført den rejse mod populist-positionen, som hun har været på vej mod i mange år. 


\section{Referencer}

Allern, S., \& Pollack, E. (2012). Mediated-Scandals-Allern-og-Pollack.pdf. In S. Allern \& E. Pollack (Eds.), The mediated Construction of Political Scandal in Four Countries (pp. 9-28). Göteborg: Nordicom.

Bennett, W. L., \& Segerberg, A. (2012). The Logic of Connective Action. Information, Communication E Society, 15(5), 739-768. https://doi.org/10.1080/1369118X.2012.670661

Bimber, B. (2014). Digital Media in the Obama Campaigns of 2008 and 2012: Adaptation to the Personalized Political Communication Environment. Journal of Information Technology and Politics, 11(2), 130-150. https://doi.org/10.1080/19331681.2014.895691

Binderkrantz, A. S., Christiansen, P. M., \& Pedersen, H. H. (2015). Interest Group Access to the Bureaucracy, Parliament, and the Media. Governance, 28(1), 95-112. https://doi.org/10.1111/gove.12089

Binderkrantz, A. S., \& Pedersen, H. H. (2017). The lobbying success of citizen and economic groups in Denmark and the UK. Acta Politica. https://doi.org/10.1057/s41269-017-0076-7

Blach-Ørsten, M. (2016). Politikkens medialisering - et ny-institutionelt perspektiv. In S. Hjarvad (Ed.) (pp. 185-2 15). Copenhagen: Hans Reitzels forlag.

Blach-Ørsten, M., \& Kristensen, N. N. (2016). Think tanks in Denmark-Media visibility and Network Relations. Politik, 19(1), 22-42.

Blach-Ørsten, M., Willig, I., \& Hemming Pedersen, L. (2017). Fra politiker til policy professionel - en analyse af danske politikeres karriereveje efter Folketinget 1981-2015. Tidsskriftet Økonomi \& Politik,

Blach-Ørsten, M., Willig, I., \& Pedersen, L. H. (2017). PR , Lobbyism and Democracy, 1-14. https://doi.org/10.1515/nor-2017-0405.1

Carty, V. (201 1). Wired and Mobilizing. Social Movements, New Technology, and Electoral Politica. New York: Routledge.

Chadwick, A. (2011a). The Political Information Cycle in a Hybrid News System: The British Prime Minister and the "Bullygate" Affair. The International Journal of Press/Politics, 16(1), 329. https://doi.org/10.1177/1940161210384730

Chadwick, A. (2011b). The Political Information Cycle in a Hybrid News System: The British Prime Minister and the "Bullygate" Affair. The International Journal of Press/Politics, 16(1), 329. https://doi.org/10.1177/1940161210384730

Christiansen, P. M., \& Rommetvedt, H. (1999). From Corporatism to Lobbyism?-Parliaments, Executives, and Organized Interests in Denmark and Norway. Scandinavian Political Studies, 22(3), 195-220. https://doi.org/10.1111/1467-9477.00013 
Cohen, M. D., March, J. G., \& Olsen, J. P. (1972). A Garbage Can Model of Organizational Choice. Administrative Science Quarterly, 17(1), 1-25. https://doi.org/10.2307/2392088

Dahl, R. A. (1961). Who Governs? New Haven: Yale University Press.

Dahlgren, P. (2005). The Internet, Public Spheres, and Political Communication: Dispersion and Deliberation. Political Communication, 22(2), 147-162. https://doi.org/10.1080/10584600590933160

Davidson, S. (2017). Public affairs practice and lobbying inequality: Reform and regulation of the influence game. Journal of Public Affairs, 17(4), 1-9. https://doi.org/10.1002/pa.1665

Etzioni-Halevy, E. (1990). Democratic-elite theory : Stabilization versus breakdown of democracy. European Journal of Sociology / Archives Européennes de Sociologie / Europäisches, 31(2), $317-$ 350. Retrieved from http://www.jstor.org/stable/23997391 Stabilisati https://doi.org/10.1017/S0003975600006093

Flyvbjerg, B. (1991). Rationalitet og magt. Bind 1 og 2. Det konkretes videnskab. København: Akademisk forlag.

Foa, R. S., \& Mounk, Y. (2016). The Democratic Disconnect. Journal of Democracy, 27(3), 5-17. https://doi.org/10.1353/jod.2016.0049

Fukuyama, F. (2014). Political Order and Political Decay. London: Profile Books.

Garsten, C., Rothstein, B., \& Svallfors, S. (2015). Makt utan mandat: de policyprofessionella $i$ svensk politik. Dialogos Förlag.

Garsten, C., \& Sörbom, A. (2017). Introduction : political affairs in the global domain. In Poser, Policy and Profit. Corporate engagement in Politics and Governance (pp. 1-24). Cheltenham and Northampton: Edward Elgar Publishing. https://doi.org/10.4337/9781784711214.00006

Grau-Larsen, A., Ellersgaard, C., \& Steinitz, S. (2016). Magtens atlas. Foreningen for elite og magtstudier.

Heclo, H. (1978). Issue networks and the executive establishment. Public Adm. Concepts Cases, 413(413), 46-57. https://doi.org/10.1016/j.annals.2015.03.003

Hoff-Clausen, E. (2009). Webkommunikation. In J. Helder, T. Bredenlöw, \& J. L. Nørgaard (Eds.) (pp. 469-499). København: Hans Reitzels forlag.

Jagers, J., \& Walgrave, S. (2007). Populism as political communication style: An empirical study of political parties' discourse in Belgium. European Journal of Political Research, 46(3), 319-345. https://doi.org/10.1111/j.1475-6765.2006.00690.x

Jensen, J. L. (2016). Nye medier og virkeligheden. In T. Olesen (Ed.), Medier, Politik og Samfund (pp. 265-285). København: Hans Reitzels forlag.

Kingdon, J. W. (2001). Agendas, Alternatives and Public Policies. Boston: Pearson Higher Education. 
Kingdon, J. W. (2015). A Model of Agenda-Setting, With Applications. Law Review, 2, 331-337. https://doi.org/10.3868/s050-004-015-0003-8

Klinger, U., \& Svensson, J. (2015). Network media logic: some conceptual clarification. In A. Bruns, G. Enli, E. Skogerbø, A. Larsson, \& C. Christensen (Eds.), Routledge companion to social media and politics. Routledge.

Kulturministeriet. (2016). Public Service - De neste ti år. Rapport fra Public Service udvalget. København.

Kulturstyrelsen, S. (2017). Mediernes udvikling i Danmark. Globaliseringens af den danske mediebranche. København.

Mintrom, M., \& Norman, P. (2009). Policy Entrepreneurship and Policy Change, 37(4), 649-668.

Mintrom, M., \& Vergari, S. (1996). Advocacy Coalitions, Policy Entrepreneurs, and Policy Change. Policy Studies Journal, 24(3), 420-434. https://doi.org/10.1111/j.15410072.1996.tbo1638.x

Mudde, C. (2004). The Populist Zeitgeist. Government and Opposition, 39(4), 542-563. https://doi.org/10.1111/j.1477-7053.2004.00135.x

Munk Christiansen, P., \& Rommetvedt, H. (1999). From Corporatism to Lobbyism? : Parliaments, Executives, and Organized Interests in Denmark and Norway. Scandinavian Political Studies, 22(3), 195-200. https://doi.org/10.1111/1467-9477.00013

Nielsen, R. K. (2011). Mundane internet tools, mobilizing practices, and the coproduction of citizenship in political campaigns. New Media \& Society, 13(5), 755-771. https://doi.org/10.1177/1461444810380863

Norris, P. (2002). Democratic Phoenix: Reinventing Political Activism. New York: Cambridge University Press. https://doi.org/10.1017/CBO9780511610073

Olsen, J. P. (1978). Folkestyre, byråkrati og korporativisme - skisse av et organisasjonsteoretisk perspektiv, (pp. 13-114). Oslo: Universitetsforlaget.

Pedersen, J. S., \& Aagaard, P. (2015). Dirigent eller dukke? Lederen i reformstaten. København: Gyldendal Public.

Rommetvedt, H., Thesen, G., Christiansen, P. M., \& Norgaard, A. S. (2012). Coping With Corporatism in Decline and the Revival of Parliament: Interest Group Lobbyism in Denmark and Norway, 1980-2005. Comparative Political Studies, 46(4), 457-485. https://doi.org/10.1177/0010414012453712

Schmidt, V. A. (2008). Discursive Institutionalism: The Explanatory Power of Ideas and Discourse. Annual Review of Political Science, 11(1), 303-326. https://doi.org/10.1146/annurev.polisci.11.060606.135342 
Schmidt, V. A. (2010). Taking ideas and discourse seriously: explaining change through discursive institutionalism as the fourth "new institutionalism." European Political Science Review, 2(1), 1-25. https://doi.org/10.1017/S175577390999021X

Schrøder, K., Blach-Ørsten, M., \& Burkal, R. (2017). Danskernes brug af nyhedsmedier 2017. Roskilde.

Schrøder, K., \& Nielsen, R. K. (2014). Danskernes brug af digitale medier og nyheder i 2014. Roskilde.

Svallfors, S. (2016a). Knowing the game : motivations and skills among partisan policy professionals. Journal of Professions and Organization, (February).

Svallfors, S. (2016b). Out of the Golden Cage: PR and the Career Opportunities of Policy Professionals. Politics and Policy, 44(1), 56-73. https://doi.org/10.1111/polp.12149

Svallfors, S. (2016c). Politics as organised combat - New players and new rules of the game in Sweden. New Political Economy, 21(6), 505-519. https://doi.org/10.1080/13563467.2016.1156662

Sørensen, M. P. (2016). Political conversations on Facebook - the participation and citizens. Media, Culture \& Society, 38(5), 664-685. https://doi.org/10.1177/0163443715620924

Togeby, L., Goul Andersen, J., Munk Christiansen, P., Beck Jørgensen, T., \& Vallgårda, S. (2003). Magt og demokrati i Danmark - hovedresultater fra Magtudredningen. Aarhus Universitetsforlag.

Zuiderveen Borgesius, F. J., Trilling, D., Möller, J., Bodó, B., de Vreese, C. H., \& Helberger, N. (2016). Should we worry about filter bubbles? Internet Policy Review, 5(1), 1-16. https://doi.org/10.14763/2016.1.401

Aagaard, P. (2016). Age of Political Communication: Democratic decay or the rise of phronetic political communication? Nordicum-Mediterarneum, 11(3). Retrieved from http://nome.unak.is/wordpress/volume-1 1-no-3-2016/conference-proceeding-volume-11no-3-2016/fourth-age-political-communication-democratic-decay-rise-phronetic-politicalcommunication/

Aagaard, P. (2017). Politik som fiktion - om en ny tids politiske kommunikation. Økonomistyring $\Xi^{2}$ Informatik, 32(3).

Aagaard, P., \& Blach-Ørsten, M. (2018). Politisk kommunikation: Nye tider og nye aktorer. København: Hans Reitzels forlag.

Aalberg, T., Esser, F., Reinemann, C., Strömbäck, J., \& de Vreese, C. H. (Eds.). (2016). Populist Political Communication in Europe. https://doi.org/10.4324/9781315623016 